\title{
EVALUATION OF POZZOLANIC REACTIVITY OF CALCINED KAOLINITE
}

\author{
C. M. G. de Souza ${ }^{1}$, S. Greiser ${ }^{2}$, E. Garcia ${ }^{3}$, V. A. Quarcioni ${ }^{4}$, Ch. Jäger ${ }^{5}$ \\ ${ }^{1,3,4}$ IPT-Institute for Technological Research, Brazil \\ ${ }^{2,5}$ BAM - Federal Institute for Materials Research and Testing, Germany \\ cmgsouza@ipt.br,edugarcia@ipt.br
}

\begin{abstract}
The need to improve the sustainability and the need for innovation in the cement industry has brought to light the practice of using additives to the cement in order to decrease $\mathrm{CO}_{2}$ emissions in industrial plants and increase the quality of cement in terms of durability and performance. Currently some additives have been employed as granulated blast furnace slag, limestone and pozzolan. The additives give mortar and concrete larger energy efficiency, gain in durability and resistance, contributing to buildings with slender structures and cheaper and durable maintenance. Besides natural pozzolan can be used artificial ones, as calcined clays, and over a range of amorphous aluminates and silicates waste, with highly reactive function as a binder material in the presence of water and calcium hydroxide. Calcined kaolinite clays were characterized using various techniques such as XRD, thermal analysis, and NMR observing ${ }^{27} \mathrm{Al}$ and ${ }^{29} \mathrm{Si}$ nuclei. The results showed that there is a structural modification of the samples, from crystalline to amorphous phases with the increasing of temperature in the calcination process. There is an improving in the reactivity of calcined clays by the range of $600^{\circ} \mathrm{C}$ to $750^{\circ} \mathrm{C}$ temperature in the reaction with calcium oxide, according to data from Chapelle test, indicating the possibility of using them as additives for cement and confirming their pozzolanic potential.
\end{abstract}

Keywords: kaolin, pozzolan, calcined clays, cement additive

\section{INTRODUCTION}

The current Portland cement industry is undergoing major changes. The questioning of their contribution to climate change and the environment has led to increasing demand for environmentally friendly and economical alternative for its production, using a based on three basic pillars: greater energy efficiency, additions to cement and alternative fuels. Also notable is the need to make the final product, where the mortar and concrete, more durable and more resistant, contributing to buildings with slender structures and cheaper maintenance and durable.

In Brazil for decades the cement industry has been using partial additions replacement for Portland cement. This can be considered a way to reduce their environmental liabilities. The additives can be found of several types available in the Brazilian market: CPII - E cement with the addition of granulated blast furnace slag; CPII - F that receives the addition of limestone filler; CPII- $Z$ which receives the addition of pozzolan [1]; CPIII with higher addition of granulated blast furnace slag [2]; and CPIV with higher addition of pozzolan [3]. The CPII-Z cement uses partial adding 6\%-14\% of pozzolan material and CPIV uses $15 \%-50 \%$, both replacing clinker. These calcined particulate materials, added in part to the clinker substitution, have predominantly amorphous microstructure [1], [2].

Besides natural pozzolana one can use artificial pozzolans, as calcined clays. Brazil is rich in kaolinite clays that can be used as pozzolans after calcination at the appropriate temperature [4], [5].

Pozzolanic chemical reactivity can be evaluated by Chapelle test [6], [7]. The NBR 15.985 standard [6], published in Brazil and the technique NF P18513 [7] published in French at same time follow, the general guidelines described by Raverdy et al. [8] with the basic difference that these two normative texts use pozzolan: calcium oxide $(\mathrm{CaO})$ 1:2 ratio to perform the test and expresses the results in $\mathrm{mg}$ of calcium hydroxide $\left(\mathrm{Ca}(\mathrm{OH})_{2}\right)$ fixed per gram of the sample.

In this work calcined kaolinite clays were characterized by various techniques such as X-ray diffraction (XRD), thermal analysis, magic angle spinning nuclear magnetic resonance (MAS-NMR), Blaine technique, BET analysis, for observing structural changes during the calcination process, correlated to formation of their meta-stable forms, improving the assessment of kaolinite clays and its reactive potential. Data were also studied and correlation between structural changes and pozzolanic reaction were compared using dedicated characterization techniques as MAS-NMR and Chapelle test.

The results showed that there is a structural modification of the samples with the calcination process of the kaolinite clay. There is an increasing from crystalline to amorphous phases, with the increasing in the temperature of calcination. Data compared between metakaolinite formation correlate to pozzolanic reaction showed a changing in the reactivity to a maximum at $700^{\circ} \mathrm{C}$ calcined sample and the possibility of using them as addictive to cement. 


\section{MATERIALS AND METHODS}

Pozzolan material were obtained from sedimentary origin kaolinite clay with chemical composition determined by classical chemical analysis as follow: $51.77 \% \mathrm{SiO}_{2}, 29.45 \%$ $\mathrm{Al}_{2} \mathrm{O}_{3} ; 2.22 \% \mathrm{Fe}_{2} \mathrm{O}_{3} ; 2.87 \% \mathrm{~K}_{2} \mathrm{O} ; 1.38 \% \mathrm{TiO}_{2}$; Fire Loss $10.58 \%$ and other lesser extent. The material preparation occurred by manual grinding with a mortar until fully passing through sieve \# 200mesh $(65 \mu \mathrm{m})$. The sample was calcined at various temperatures from $500^{\circ} \mathrm{C}, 550^{\circ} \mathrm{C}, 600^{\circ} \mathrm{C}, 650^{\circ} \mathrm{C}$, $700^{\circ} \mathrm{C}, 750^{\circ} \mathrm{C}, 800^{\circ} \mathrm{C}$ and $850^{\circ} \mathrm{C}$ after two hours without heating ramp in a muffle furnace the material was cooled by forced ventilation to gain amorphousness.

$\mathrm{X}$-ray diffraction was performed a Rigaku Windmax 1000 equipment, with $2^{\circ}$ ramp, $1^{\circ}$ slit. An acceleration voltage of $40 \mathrm{kV}$ and a current of $20 \mathrm{~mA}$ were applied. The thermal analysis (TG / DTG / DTA) were performed using TA Instruments SDT 2960 equipment in an open alumina crucible, with Nitrogen $100 \mathrm{~mL} / \mathrm{min}$ purge, at a heating rate of $10^{\circ} \mathrm{C} / \mathrm{min}$. The ${ }^{27} \mathrm{Al}$ magic angle spinning (MAS) NMR spectra were obtained at the frequency of $156,38 \mathrm{MHz}(14,1$ Tesla) on a BRUKER Avance 600 spectrometer using $2.5 \mathrm{~mm}$ probe with $25 \mathrm{kHz}$ spinning speed rotation, $5.5 \mu \mathrm{s} 90^{\circ}$ pulse, and $2 \mathrm{~s}$ repetition time. ${ }^{29} \mathrm{Si}$ MAS NMR spectra were obtained at the frequency of $79.49 \mathrm{MHz}$ (9.4 Tesla) on a BRUKER 400 DSX spectrometer using $7 \mathrm{~mm}$ probe with $6.5 \mathrm{kHz}$ spinning speed rotation, $3.1 \mu \mathrm{s} 90^{\circ}$ pulse, and 5-120 s repetition time. Blaine permeability was measured according to Brazilian standard NBR NM67 [10] and laser BET granulometric analysis [11] were performed on a Gemini V2.00 Micrometrics equipment on nitrogen atmosphere with $3 \mathrm{~s}$ equilibration time and 711.945 $\mathrm{mmHg}$ sat. pressure. The pozzolanic reactivity analysis was performed with lime reaction according to the Chapelle test using 1:2 pozzolan- $\mathrm{CaO}$ ratio in 16 hours test at $90^{\circ} \mathrm{C}( \pm 5)$, with the result expressed as milligrams per gram of $\mathrm{CaO}$ fixed material.

\section{RESULTS AND DISCUSSIONS}

\subsection{XRD Characterization}

Figure 1 illustrates the XRD pattern of kaolinite and calcined kaolinite clays in different temperatures. The samples contain both crystalline (kaolinite, muscovite and quartz plus traces of potassium feldspar). The broad hump between 20 and $30^{\circ}$ (at $2 \Theta$ values) indicates the presence of amorphous phases which increases with increasing calcination temperature, to a maximum at $700^{\circ} \mathrm{C}$ calcined sample.

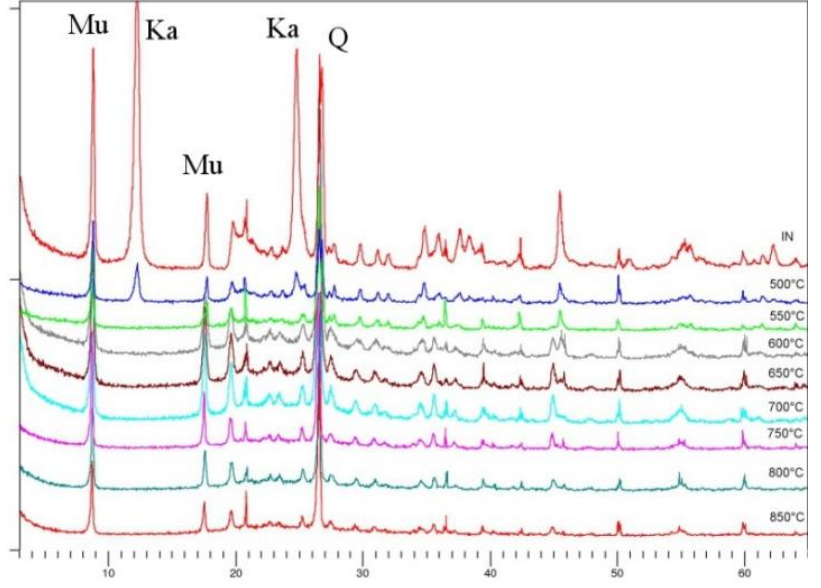

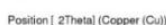

Fig. 1 - Overlapping diffraction patterns of fresh (IN) and raw material in various calcination temperatures. Highlight of major peaks: $\mathrm{Mu}=$ Muscovite, $\mathrm{Ka}=$ kaolinite and $\mathrm{Q}=$ quartz.

\subsection{DTA Characterization}

The DTA curves shown in Figure 2 shows an endothermic peak near $520^{\circ} \mathrm{C}$, due to the dehydroxylation of kaolinite in the natural sample and confirmed the presence of mineral compounds in the material [4], [9]. By 6.9\% calculated hydroxyl group losses can be inferred that the kaolinite corresponds to approximately $50 \%$ in the sample. The dehydroxylation peak was also observed sample calcined at $500^{\circ} \mathrm{C}$. TG data showed that the material gain mass stability from $700^{\circ} \mathrm{C}$ calcined sample.

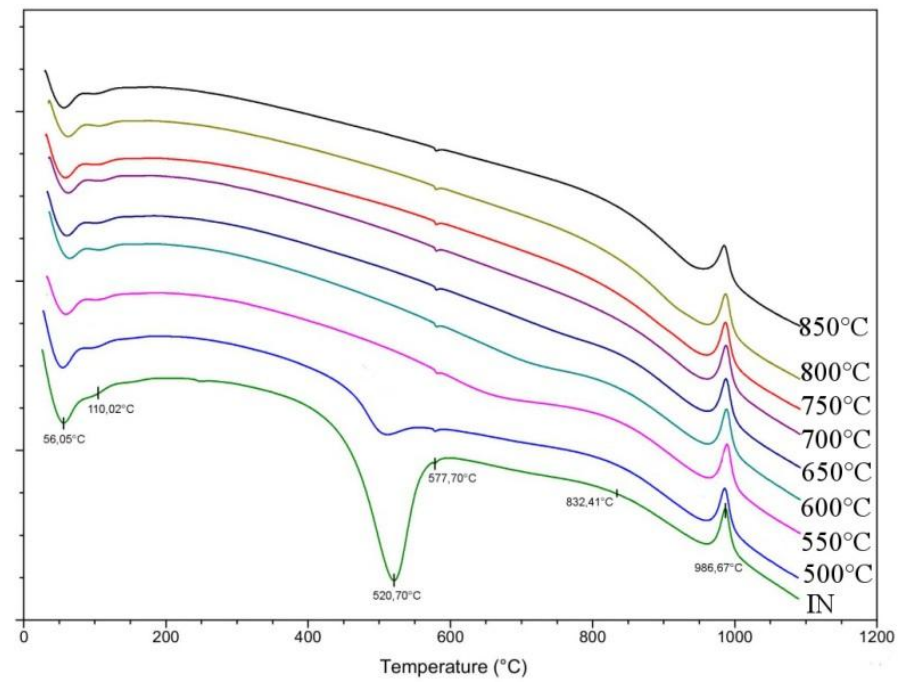

Fig. 2 - Differential thermal analysis curves at different temperatures of calcination. 


\subsection{Blaine, BET characterization}

The particles of the kaolinite clay in nature, manually grounded, are largely formed by spheroids with small dimensions and high specific surface area of $19.530 \mathrm{~cm}^{2} / \mathrm{g}$ as measured by Blaine method and the value of $166.200 \mathrm{~cm}^{2} / \mathrm{g}$ analyzed by BET as showed in Table 1 . Both techniques showed that sample calcined at $550^{\circ} \mathrm{C}$ has a significant loss of surface area by agglomeration of particles. When analyzed by Blaine technique, sample calcined at $600^{\circ} \mathrm{C}$ showed the tendency of particles to stabilize in spheroid shape, however, the BET technique showed that these particles undergo changes in its internal structure by opening the layers and leaving more exposed surface for reactivity. It is important to observe that temperatures above $600^{\circ} \mathrm{C}$ are related to the early loss of oxygen bridges and disruption of the alumina layer by changing the coordination of aluminum.

At $650^{\circ} \mathrm{C}$ the specific surface area returns to the value of $162.000 \mathrm{~cm}^{2}$ indicating a reorganization of the internal structure of the particle which makes the area similar to that material calcined at $550^{\circ} \mathrm{C}$. The tendency of gradual increase in specific surface area from temperature between $650^{\circ} \mathrm{C}$ and $750^{\circ} \mathrm{C}$ analyzed by the BET technique showed area gain by increasing the amount of amorphous keeping the size and shape of spheroid particles.

At $750^{\circ} \mathrm{C}$ calcination temperature the BET determination of surface area was slightly larger and the one measured by Blaine was slightly smaller than the calcination at $700^{\circ} \mathrm{C}$, resulting in more particles agglutinated, and more amorphous. Considering the results obtained from the two techniques, they indicate a reduction of surface area from clay calcined at $800^{\circ} \mathrm{C}$, both the external and internal area of the spheroids sample.

Table 1 - Specific surface area of the samples.

\begin{tabular}{|c|c|c|}
\hline Sample & Blaine Technique & BET Technique \\
\hline in nature & 19,550 & 166,200 \\
\hline $550^{\circ} \mathrm{C}$ & 17,701 & 161,100 \\
\hline $600^{\circ} \mathrm{C}$ & 17,160 & 175,000 \\
\hline $650^{\circ} \mathrm{C}$ & 17,020 & 161,800 \\
\hline $700^{\circ} \mathrm{C}$ & 17,170 & 165,200 \\
\hline $750^{\circ} \mathrm{C}$ & 16,850 & 171,100 \\
\hline $800^{\circ} \mathrm{C}$ & 16,360 & 170,700 \\
\hline
\end{tabular}

\subsection{Nuclear Magnetic Resonance}

The ${ }^{29} \mathrm{Si}$ MAS-NMR spectra of kaolinite clay calcined in different temperatures are shown in Figure 3. Spectra showed a peak shift from $90 \mathrm{ppm}$ to $105 \mathrm{ppm}$ with the increasing of calcination temperature, which could be related to structural changes from high crystalline to high amorphous phases by increasing the number of $\mathrm{Q}_{4}(3 \mathrm{Al})$ structure to $\mathrm{Q}_{4}(1 \mathrm{Al})$ and $\mathrm{Q}_{4}(4 \mathrm{Si})$. Sample calcined at $500^{\circ} \mathrm{C}$ showed a peak at $-91.5 \mathrm{ppm}$ due to kaolinite structure still present in the sample. This signal has less intensity from sample calcined $550^{\circ} \mathrm{C}$. Sample calcined at $800^{\circ} \mathrm{C}$ and $850^{\circ} \mathrm{C}$ showed peaks at $-100 \mathrm{ppm}$ and $-105 \mathrm{ppm}$ due probably to the formation of $\mathrm{Q}_{4}(1 \mathrm{Al})$ e $\mathrm{Q}_{4}(0 \mathrm{Al})(4 \mathrm{Si})$ structure in the samples.

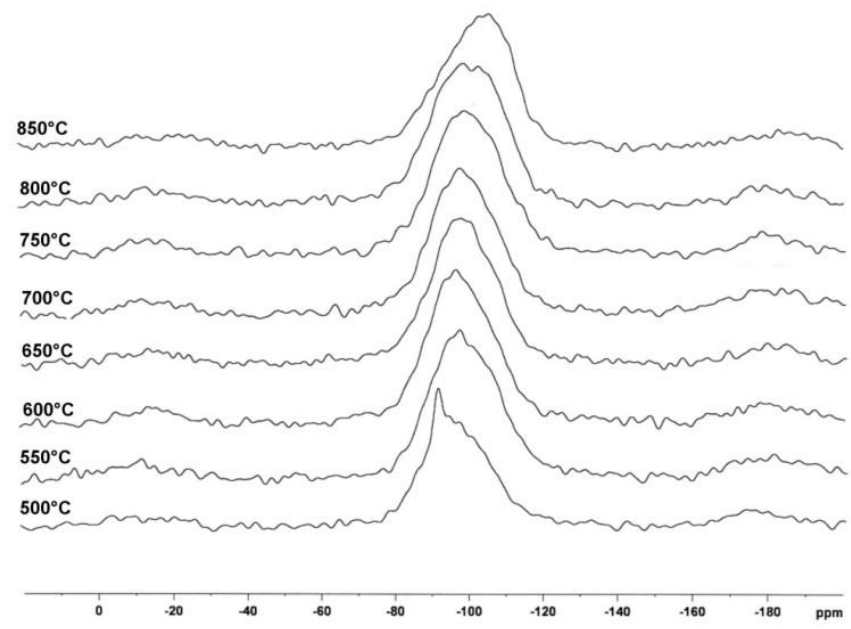

Fig. 3 - Evolution of the ${ }^{29} \mathrm{Si}$ MAS-NMR spectra in calcined samples at different temperatures.

Observing the ${ }^{27} \mathrm{Al}$ MAS NMR spectra showed in Figure 4 it can be observed a significant change in coordination of the Aluminum sites in the samples, according to the increasing of calcinations temperature. The sample calcined at $500^{\circ} \mathrm{C}$ presents a sharp peak at approximately $0 \mathrm{ppm}$, referred to the kaolinite phase still present in the clay. This peak is characteristic of octahedral $\mathrm{Al}(\mathrm{Al}(\mathrm{VI}))$. When the kaolinite is calcined to higher temperatures the intensity of this peak decreases and two lines in approximately 30 and 60ppm increases indicating respectively an increase in aluminum- $\mathrm{V}$ $(\mathrm{Al}(\mathrm{V}))$ and aluminum-IV (Al(IV)) sites. Calcined samples at $700^{\circ} \mathrm{C}$ and $750^{\circ} \mathrm{C}$ showed the highest $\mathrm{Al}(\mathrm{V})$ peaks (slightly higher at $700^{\circ} \mathrm{C}$ ) over $\mathrm{Al}(\mathrm{IV})$ and $\mathrm{Al}(\mathrm{VI})$.

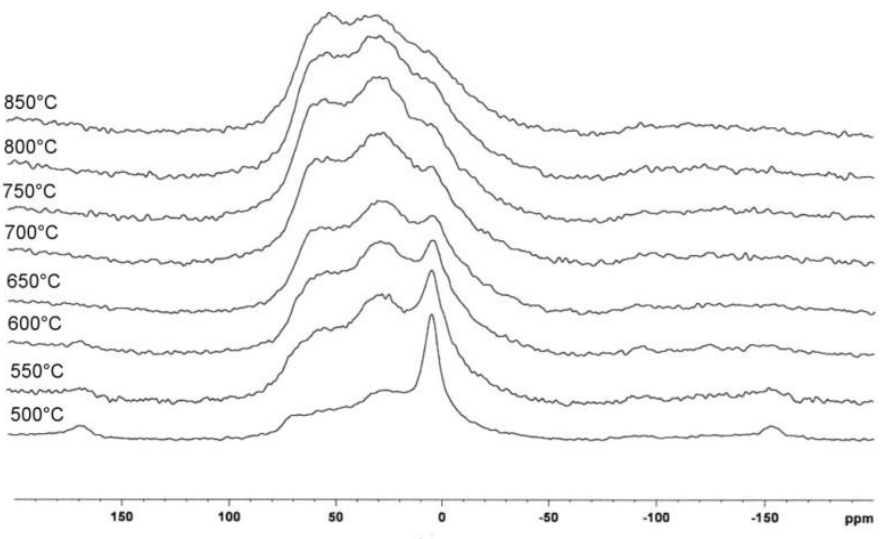

Fig. 4 - Evolution of the ${ }^{27}$ Al MAS-NMR spectra of calcined samples in different temperatures. 
The evolution of the transformation observed in the ${ }^{27} \mathrm{Al}$ and ${ }^{29} \mathrm{Si}$ MAS-NMR spectra suggests that silicates are freed from their connections sheet of alumina with increasing temperature to a maximum of $700^{\circ} \mathrm{C}$, when it begins larger change in chemical shift in ${ }^{29} \mathrm{Si}$ spectra and a small decrease in the proportion $\mathrm{Al}(\mathrm{V})$, corresponding to structural modification of metakaolin back to promote higher condensed silicate network with less aluminum contained links between aluminates and silicates.

\subsection{Chapelle test}

The results of the tests performed with standard NBR 15895 [6] in the calcined samples showed a level of reactivity between $650^{\circ} \mathrm{C}$ and $750^{\circ} \mathrm{C}$, with a tendency to peak at $700^{\circ} \mathrm{C}$, as shown in Figure 5. It is possible to observe that there is a smooth trend pointing to $700^{\circ} \mathrm{Cin}$ the assay, like more reactive material.

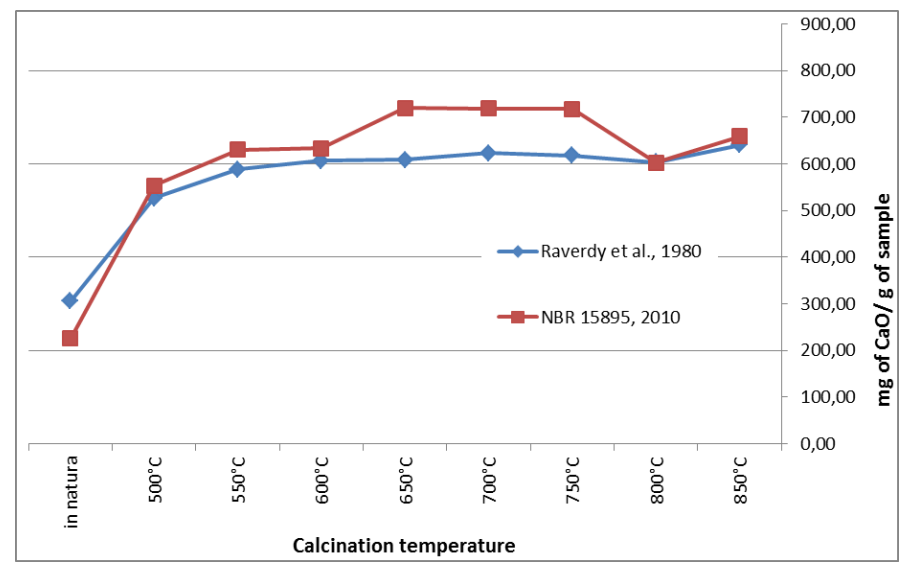

Fig. 5 - Results of the Chapelle test performed as Raverdy et al. [8] and NBR 15985 [6].

In a preliminary study Sanz et al. [12] raised a suspicion of correspondence between reactivity observed and $\mathrm{Al}(\mathrm{V})$ sites in the samples. With the quantification of this $\mathrm{Al}(\mathrm{V})$ by integrating the peak areas it was observed that this species has a significant evolution from the calcination at $600^{\circ} \mathrm{C}$ and increases up to $43.7 \%$ of the total aluminum in the sample when calcination is carried out at $700^{\circ} \mathrm{C}$, with a lightly decreasing for $750^{\circ} \mathrm{C}$ calcined sample. The sample to $800^{\circ} \mathrm{C}$ temperature suggests that this modification of the structure of the sheet silicates more sharply diminished reactivity of the change in the coordination of the aluminum

Figure 6 showed a direct and proportional correlation between the amounts of aluminum $\mathrm{V}$ obtained by ${ }^{27} \mathrm{Al}$ MAS-NMR spectra with pozzolanic reactivity of metakaolin obtained by Chapelle tests for each calcined sample. It was observed that the evolution calcination temperature of the kaolinite sample correspond to a proportionally larger amount of the reactive aluminum $\mathrm{V}$ sites. These data indicate a high correlation between the NMR techniques with Chapelle test.

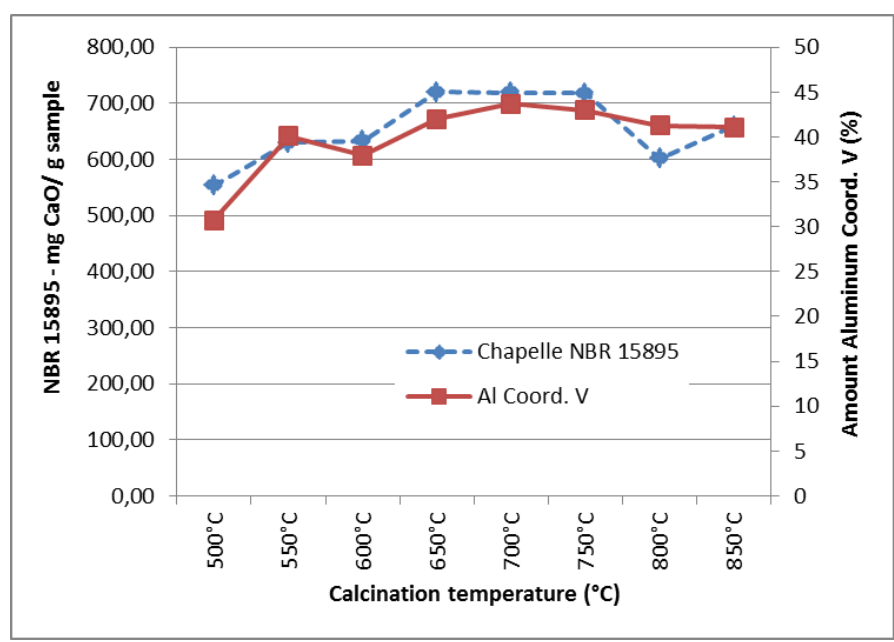

Fig. 6 - Correlation between pozzolanic reaction observed by Chapelle test and percentage of $\mathrm{Al}(\mathrm{V})$ obtained by ${ }^{27} \mathrm{Al}$ MASNMR experiment.

\section{CONCLUSIONS}

All correlated techniques showed that there is a level of pozzolanic reactions between the samples calcined at temperatures between $600^{\circ} \mathrm{C}$ and $750^{\circ} \mathrm{C}$ with a higher reactivity closely related to the specific area measured by Blaine method. In this range of temperature of calcination there is smaller coalescence of material as showed by Blaine specific area. The evolution in the calcination temperature produces larger particles, mainly in the range above $45 \mu \mathrm{m}$, as characterized by laser particle size. The changes highlighted by technique BET / Blaine collaborate to better understand the behavior of particles, not only with respect to their specific area, but also with respect to the same format throughout the various calcination temperatures.

The pozzolanic reactivity measured by Chapelle test using pozzolan: $\mathrm{CaO}$ 1:2 ratio as described by the current NBR 15.985 was more appropriate than the $1: 1$ ratio originally proposed by Raverdy et al in 1980, and actual Chapelle tests showed the presence of a level of reactivity between the samples calcined at temperatures between $650^{\circ} \mathrm{C}$ and $750^{\circ} \mathrm{C}$ with the tendency of higher reactivity at $700^{\circ} \mathrm{C}$.

${ }^{29} \mathrm{Si}$ and ${ }^{27} \mathrm{Al}$ MAS-NMR techniques of the calcined samples showed that there is a structural modification of the samples, from crystalline to amorphous phases with the increasing of temperature in the calcination process. Which means a change in silicon and aluminum coordination sites and this is related to the reactivity of the samples, as compared with Chapelle tests. The higher amount of $\mathrm{Al}(\mathrm{V})$ showed a higher reactivity of the calcined samples, with the release of the silicates sheet for reactivity. 


\section{REFERENCES}

[1] ABNT - NBR 11,578 - Cement Compound Portland: specification, Rio de Janeiro, Brazil, 1996.

[2] ABNT - NBR 5735 - Portland Cement Blast Furnace, Rio de Janeiro, Brazil, 1991.

[3] ABNT - NBR 5736 - Pozzolanic Cement Porland, Rio de Janeiro, Brazil, 1991.

[4] V. S. Ramachandran et al., Handbook of Thermal Analysis of Construction Materials. Ottawa: ed. Willian Andrew Publishing, New York Institute for Research in Construction, National Research Council of Canada, 2002.

[5] Pérsio de Souza Santos, Ciência e Tecnologia das Argilas. ed. Edgard Blücher, Universidade de São Paulo, São Paulo, Brazil, vol. 1,2 and 3, 1989.

[6] ABNT - NBR 15,895 - Pozzolanic Materials Determination of calcium hydroxide content fixed - Chapelle method, Rio de Janeiro, Brazil, 2012.

[7] AFNOR - NF P18,513 - Métakaolin, Addition Puozolanique pour Betons - Définition, Specifications, Crìteres de Conformité, 2010.

[8] W. Raverdy et al., Appréciation de látivité puozolanique des Constituants Secundaries, In: congress International de la Chimie des Ciments, Paris, vol. III and IV, 1980.

[9] W. Smykatz-kloss. Differential Thermal Analysis: Application and Results in Mineralogy, New York, ed. Springer-Velag, 1974.

[10] ABNT - NBR NM67 - Determination of fineness by air permeability method (Blaine method), Rio de Janeiro, Brazil, 1998.

[11] BET - Brunauer, Emmett and Teller test, Adsorption of Gases in Multimolecular Layers, 1938.

[12] J. Sanz et al., Aluminum-27 and Silicon-29 Magic-Angle Spinning Nuclear Magnetic Resonance Study of the KaoliniteMullite Transformation, Journal of the American Ceramic Society, vol. 71, C418-C421, 1988.

\section{BIOGRAPHIES:}

Claudia Maria G. de Souza has received her $\mathrm{PhD}$. from University of São Paulo, São Paulo, Brazil. Currently working as researcher in the Chemical Analysis Lab. at IPT - Institute for Technological Research. Her research interests are in the field of nuclear magnetic resonance applied to material characterization.

Eduardo Garcia has received the Msc. degree from the IPTInstitute for Technological Research, São Paulo, Brazil. Currently he is working as Professor in the department of Civil Engineering at Universidade Paulista, and researcher at IPT. His research interests include alkaline activation clays and alternative materials for cement addition like pozzolans.

Sebastian Greiser has received his Graduate degree from Leipzig University, Leipzig, Germany. Currently he is $\mathrm{PhD}$ student at the BAM- Federal Institute for Materials Research and Testing, Berlin, Germany. His research interests are in the field of geopolymers.

Valdecir Angelo Quarcioni has his DSc. from University of São Paulo, São Paulo, Brazil. Currently working as head of Construction Materials Laboratory of IPT-Institute for Technological Research. His interests are chemistry of building materials, with emphasis on binders, waste materials, addition for Portland cements and durability of mortar and concrete.

Christian Jäger has received his Ph.D. from the University of Jena, Germany. Currently working as head of the NMR group at the BAM- Federal Institute for Materials Research and Testing, Berlin, Germany. His research interests are in the field of nuclear magnetic resonance applied to material characterization. 